ENTREPRENEURSHIP AND SUSTAINABILITY ISSUES

ISSN 2345-0282 (online) http://jssidoi.org/jesi/ 2020 Volume 8 Number 1 (September)

http://doi.org/10.9770/jesi.2020.8.1(32)

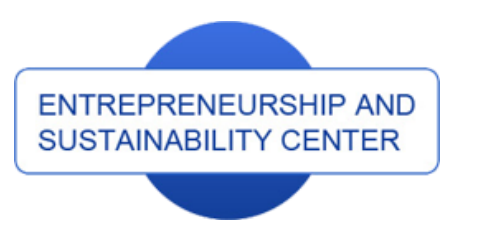

Publisher

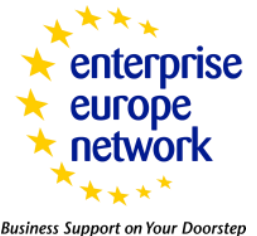

CASPA
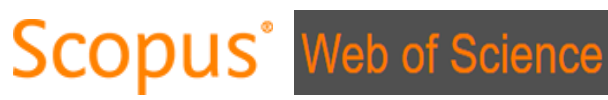

http://jssidoi.org/esc/home

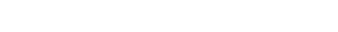 \\ (1) \\ EFFECTS AND MOTIVATION OF POLITICAL - ECONOMIC COOPERATION BETWEEN TWO COUNTRIES: A CASE STUDY OF SLOVAKIA AND AUSTRIA*

\author{
René Pawera ${ }^{1}$, František Vojtech ${ }^{2}$, Michal Levický ${ }^{3}$, Stanislav Filip $^{4}$ \\ ${ }^{1}$ Comenius University in Bratislava, Slovak Republic \\ ${ }^{2,4}$ School of Economics and Management in Public Administration in Bratislava, Slovak Republic \\ ${ }^{3}$ Constantine the Philosopher University in Nitra, Slovak Republic
}

E-mails: $\underline{{ }^{1} \text { rene.pawera@fm.uniba.sk },{ }^{2} \text { frantisek.vojtech@vsemvs.sk },{ }^{3} \text { mlevicky@gmail.com },{ }^{4} \text { stanislav.filip@vsemvs.sk }}$

Received 10 March 2020; accepted 15 June 2020; published 30 September 2020

\begin{abstract}
The political and economic relations between Slovakia and Austria reflect the geographical situation in Central Europe, the change in the political climate after 1989 and, finally, the establishment of the Slovak Republic and its successful efforts to join EuroAtlantic structures and the European Union. Subsequently, entry into the Schengen area and the European Monetary Union. We focus on some aspects of mutual cooperation between two long-standing neighboring states from the point of view of the theoretical basis of international political and economic cooperation. The aim of the case study is to analyze the successes of international cooperation between Austria and Slovakia, to identify open issues in bilateral relations between Slovakia and Austria, and to predict trends in the coming period. The ambition of this study is also to highlight areas that can be considered key to bilateral cooperation. International cooperation is a very broad field in which general and specific scientific methods can be used. Given the type of study, we decided to use selected general scientific methods, which we adapted to the specifics of examining economic relations between countries. Based on the results, we can say that the possibilities of economic cooperation between Austria and Slovakia are far from exhausted. Joint projects in the field of transport and energy infrastructure, energy security and diversification of energy sources are several examples where cooperation lasts for several years and has a perspective for the future. The increase in cooperation is in the field of foreign trade, in the field of foreign investment, but also in the growing level of services, including the increase in cooperation in the field of tourism. Since its inception, Slovakia has become an important trading partner of Austria, with trade with Austria catching up with trade Slovakia with traditional partners - with neighbors (Poland, Hungary).
\end{abstract}

Keywords: economic cooperation; a case study; Slovakia; Austria

Reference to this paper should be made as follows: Pawera, R., Vojtech, F., Levický, M., Filip, S. 2020. Effects and motivation of political - economic cooperation between two countries: a case study of Slovakia and Austria. Entrepreneurship and Sustainability Issues, 8(1), 454-470. http://doi.org/10.9770/jesi.2020.8.1(32)

JEL Classifications: R11

\footnotetext{
* This paper was supported by the project, which has received funding from the Grant Research Agency of the School of Economics and Management in Public Administration in Bratislava, of the Slovak Republic
} 


\section{ENTREPRENEURSHIP AND SUSTAINABILITY ISSUES}

ISSN 2345-0282 (online) http://jssidoi.org/jesi/

2020 Volume 8 Number 1 (September)

http://doi.org/10.9770/jesi.2020.8.1(32)

\section{Introduction}

From a historical point of view, the cooperation between Slovakia and Austria is a logical fact. In the course of history, but especially since the revolution in 1848 in Austria - Hungary, when Slovak historians, for obvious reasons, sided with the Austrian side, the relations between the two nations have converged (Schulze, M. S.; Wolf, N. (2012)). Relations did not suffer even after the Second World War, because the Czechoslovak government dealt with Germany and Hungary. For Slovakia is Austria a priority relation of foreign policy activities, due to its close location and the maturity of the economy, Austria is a priority relation of foreign policy activities. Austria does not lag behind in similar activities due to the opportunity to apply its assets in the dynamically developing economy of Slovakia. This is supported by a constructive foreign and economic policy and intensive bilateral economic, cultural and political dialogue at all levels. The achieved level of such mutual relations is highly appreciated by the European Union in periodic evaluations (Rostetska, S.; \& Naumkina, S. (2019)). Examples of positive political cooperation between Slovakia and Austria include the highway, river and rail interconnections of major cities (Tóth, B. (2019)), which are being dynamized by the TEN (Trans-European Transport Network) project, and the Slovak-Austria Cross-border Cooperation Program 2007-2013 within the European Union Regional Economic Policy.

\section{Economic and political characteristics of cooperating countries}

\subsection{Realities of the economy of the Republic of Austria}

After the end of the First World War and the monarchy, the First Republic was declared in 1918. In 1938, Austria was incorporated into the National Socialist German Empire and lost its state independence. After the end of World War II, Austria was first occupied by the Allies, but in 1955 it regained its sovereignty by the State Treaty. Austria has been a member of the European Union since 1 January 1, 1995. Under the agreement of the countries that occupied Austria from 1945 to 1955, independent Austria was declared "permanently neutral" (Luif, P. (2016)). For this reason, it has been granted an exemption within the EU and thus maintains its neutrality, even with regard to the EU's Common Foreign and Security Policy. Austria is also not a member of NATO.

Austria's population was estimated to be nearly 9 million (8.9) in 2020 by the Statistik Austria. It has a relatively low population density of about 98 inhabitants per $\mathrm{km}^{2}$ (Eurostat). The Roman Catholic Church has complete dominance in religion. A large part of Austria is uninhabited, as $2 / 3$ of the country is the Alps. In fact, one in three Austrians lives in five major cities in the country: Vienna (1 540000 inhabitants), Graz (240 000 inhabitants), Linz (205 000 inhabitants), Salzburg (148 000 inhabitants) and Innsbruck (122000 inhabitants). The official language is German. The population is $98 \%$ German-speaking. The remaining two percent are Slovenian (Kärnten), Croatian (in Burgenland), Hungarian, Czech and Slovak national groups and linguistic minorities (Statistics Austria (2010)). As a federal state Austria consists of nine federal states. The federal capital Vienna is also one of the nine federal states. Each of the nine federal states is administered by the Federal Government, headed by the Prime Minister.

Austria is a parliamentary republic and is based on the basic principles of democracy and the division of power. The Economist Intelligence Unit rated Austria a "full democracy" in 2019 (The Economist Intelligence Unit (2019)). The highest representative of the state is the federal president, whose term of office lasts six years. The two chambers of parliament are the National Council (Nationalrat) and the Federal Council (Bundesrat). They are the legislatures. The Federal Government is chaired by the Federal Chancellery. The Federal Constitution, the State Treaty, the Neutrality Act, as well as the Act of Accession to the EU form the constitutional foundations of the republic. There are five parties in the National Council in 2020 (Austrian Interior Ministry (2019)), two government parties: The Austrian People's Party (Österreichische Volkspartei - ÖVP) and the Austrian Green Party (Die Grünen Österreich) and the other parties of the Social Democratic Party of Austria (Österreichische 


\section{ENTREPRENEURSHIP AND SUSTAINABILITY ISSUES}

ISSN 2345-0282 (online) http://jssidoi.org/jesi/ 2020 Volume 8 Number 1 (September) http://doi.org/10.9770/jesi.2020.8.1(32)

Volkspartei - ÖVP). Sozialdemokratische Partei Österreichs - SPÖ), the Freedom Party of Austria (Freiheitliche Partei Österreichs - FPÖ), as well as New Austria and the Liberal Forum (Das neue Österreich - NEOS).

Austria is the 4th richest country in the EU. As in most advanced economies, the decisive share in the national economy is represented by the services sector (70.4\%). The share of the manufacturing sector $(22.0 \%)$ can be considered above average and stable in the long run. The growth of industrial production increased in 2018 by $8.2 \%$ in nominal terms. The structure of the Austrian economy is very modern and diverse. Austria is characterized by a high proportion of state-owned enterprises. Almost half of the land is used for agriculture. In terms of raw materials, Austria has lead, brown coal, iron ore, zinc, gas and oil. An important raw material is wood. There is also a large amount of magnesite in Austria. The most important industrial companies are in the iron, steel, engineering, chemical and food industries. The electrical engineering and electronics sectors also play an important role. Tourism is one of the best known and most important sectors of the economy. Foreign trade is crucial for the country. The share of exports of goods and services in GDP reached 54.5\% in 2018. Exports are widely diversified and therefore less prone to economic crisis. The strong dependence of the Austrian economy on mutual trade with EU countries is evidenced by the fact that up to $69.91 \%$ of exports and $70.62 \%$ of imports go to / from EU countries, with Germany, the USA, Italy, France and Switzerland being the most important trading partners. The country is characterized by close ties to the German economy and strong dependence on bilateral trade relations with Germany (Eurostat).

On October 26, 1955, the Austrian Parliament passed the law on neutrality. Subsequently, Austria joined the EU on January 1, 1995. Due to neutrality, this country has been granted an exemption in the EU due to the common foreign and security policy. Austria is not even a member of NATO. Austria does not record a general government deficit in 2018, but instead a surplus of $0.1 \%$, which the Austrians managed to do at the national level for the first time since 1974. The forecast for 2019 speaks of a public finance surplus of $0.4 \%$, in 2020 it should be up to $0.7 \%$. Compared to 2017, state revenues increased by 8.6 billion EUR, and reached the value of 178.6 billion EUR, which represents an increase of 4.8\%. Government expenditures increased only slightly, namely $2.9 \%$, ie 5.3 billion euros, reaching a value of 187.2 billion. euros. The state treasury was also filled thanks to a high increase in property and income tax revenues - 8.4\% compared to 2017, which represented an increase of approximately 4 billion euros (Eurostat; MFEA SR (2019)).

In the field of employment, Austria is one of the most successful EU member states. With an unemployment rate of $4.3 \%$, it is well below the EU average. Unemployment has the character of structural unemployment (Christl, M., Köppl - Turyna, M.; Kucsera, D. (2016)). One of the reasons for low unemployment is the dual education system (Graf, L. (2016)), which guarantees the industry a supply of skilled labor from apprentices and industrialists. Another reason is the flexibility of the workforce and the legalization of undeclared work and parttime work. From January 1, 2013, conditions for entrepreneurs have improved. Compared to 2011, the number of employees also increased by 35000 to 3.467 million employees (highest employment since 1945). The unemployment rate reached $4.9 \%$ in 2018 , while in 2019 the unemployment rate is expected to fall by $0.3 \%$. In December 2018, AMS Österreich (Labor Office) registered a total of 355637 unemployed, of which 106,693 were long-term unemployed. In February 2019, fewer unemployed were registered than in the last month of 2018, namely 343 400. Migrants are not expected to have a significant impact on employment (Renger, B. et al. (2017)). The average hourly price of labor reached $33.96 €$ in 2018 , which means an increase of $2.8 \%$ compared to 2017 (Eurostat). In the manufacturing sphere, the average price of labor was $36.87 €$, in the provision of services 32.45 $€$. The highest values were recorded in the financial and insurance sphere $-58.02 €$, and also in the energy industry $-54.53 €$. On the contrary, the least financially valued work is in the gastronomy and hotel industry $18.07 €$. In 2018 , employers paid $73 \%$ of total wage costs and $27 \%$ of indirect costs. The highest share of indirect labor costs was in the sphere of construction, namely $31 \%$. 


\section{ENTREPRENEURSHIP AND SUSTAINABILITY ISSUES}

ISSN 2345-0282 (online) http://jssidoi.org/jesi/ 2020 Volume 8 Number 1 (September) http://doi.org/10.9770/jesi.2020.8.1(32)

Employment and economic growth are inseparable. Gross domestic product reached in 2018 value 386.09 billion $€$, which, per capita represents $39292 €$ with regard to the standard of purchasing power. Austria's real GDP growth reached $2.7 \%$ in 2018, up from 2. \% a year earlier. The inflation rate in Austria reached $2.1 \%$ in 2018. The increase was due to significantly higher prices of fuels and heating oil. The cost of living is relatively high. The price level is about 5\% above the EU average, at the same time higher than in neighboring Germany and Italy (Eurostat). Austrian industry is the main contributor to economic growth. We can call it a subcontracting industry. It is concentrated mainly in Vienna, Linz, Salzburg and Innsbruck. Once the state-owned industry was largely privatized. The most famous are OMV AG and Siemens. The Austrian steel industry increased its production by $10 \%$ in 2011 and production is expected to increase in 2012 as well. There are increases in almost all sectors. An example is the chemical industry, where there is intensive cooperation between the economy and science. This ensures competitiveness on world markets (MFEA SR (2019)). Services are a major contributor to stability and economic growth in this country. From the point of view of tourism, Austria is one of the most visited countries in Europe (Popescu, A. (2017)). Annually, the income from tourism per person represents $1657 €$, which is the 2nd place in the world. The share of tourism in total GDP is about $6 \%$. As a result of the economic crisis, accommodation fell by only $20 \%$ in 2010 and turnover fell by 2-3\%. However, the situation has been improving since 2011 (Eurostat). Austria supports international trade and trade without barriers and seeks to create favorable conditions for foreign investors (Lomachynska, I.; Yakubovskiy, S.; Plets, I. (2019)). Under the Federal Ministry of the Economy, Family and Youth, a state agency was set up to support the inflow of foreign investment under the name of the Austrian Business Agency. The main goal of this organization is to support foreign investors in establishing themselves on the Austrian market. The basic preconditions that are Austria's most important source of competitive advantage on an international scale are political and social stability, legal certainty and high law enforcement, a high standard of living and an education system.

\subsection{Realities of the economy of the Slovak Republic}

The Slovak Republic was established in 1993 by the disintegration of the Czech and Slovak Federal Republic into an area of $49035 \mathrm{~m}^{2}$, which in 2019 was inhabited by 5450421 inhabitants (Eurostat). The capital of the Slovak Republic is Bratislava, situated in the southwestern part of Slovakia on the borders with Hungary and Austria. Slovakia is a democratic state. The Economist Intelligence Unit rated Slovakia a "Flawed democracy" in 2019 (The Economist Intelligence Unit (2019)). State power in it belongs to the citizens. They participate in power through their elected political representatives elected in democratic elections. Power in the state is divided into 3 independent components: legislative, executive and judicial. The highest representatives of the political system in the Slovak Republic are the National Council of the Slovak Republic, the Government of the Slovak Republic and the President of the Slovak Republic (Horvath, P. (2017)). The National Council of the Slovak Republic is the only constitutional and legislative institute of the Slovak Republic. It is based in Bratislava and has legislative power. Members of the National Council of the Slovak Republic are elected in general, equal and direct elections by secret ballot. The number of Members is 150 and their term of office is four years. All citizens over the age of 18 can vote. A citizen of the Slovak Republic can become a deputy from the age of 21 . Parliament is headed by a Prime Minister and Deputy Prime Ministers, Members work in committees. In the political system of the Slovak Republic, the parliament approves laws, the state budget, and assesses the activities of the government. The head of the Slovak Republic is the president. The President represents the Slovak Republic externally and internally, and by his decision-making he ensures the proper functioning of constitutional institutions. The President is elected by the citizens of the Slovak Republic in direct elections by secret ballot for five years. The Government of the Slovak Republic is the highest institution of executive power in the political system of the Slovak Republic. The government is formed after the elections, the winners of the elections form a coalition (alliance), the political parties, which have a minority representation in parliament, form the opposition. The Prime Minister is appointed and removed by the President of the Slovak Republic. On the proposal of the Prime Minister, the President of the Slovak Republic appoints and dismisses other members of the Government and entrusts them with the management of ministries. The judiciary in the Slovak Republic has two levels. The system of courts in the Slovak Republic is divided into: general courts and military courts. The system of general courts in the Slovak 


\section{ENTREPRENEURSHIP AND SUSTAINABILITY ISSUES}

ISSN 2345-0282 (online) http://jssidoi.org/jesi/ 2020 Volume 8 Number 1 (September) http://doi.org/10.9770/jesi.2020.8.1(32)

Republic consists of the Supreme Court of the Slovak Republic, regional courts and district courts. The Constitutional Court with its seat in Košice City has an independent legal status and does not belong to the system of general courts. Military courts decide on criminal cases involving members of the military. Citizens of the Slovak Republic can appeal to the European Court of Human Rights, based in Strasbourg, France. Slovakia is a full member of the European Union, NATO, OECD and the Schengen area. Slovakia adopted the euro on January 1, 2009 and thus became the 16th member state of the euro area because it met all the required Maastricht criteria. Despite the global economic crisis, which caused a decline in GDP, Slovakia maintains a very good position in GDP growth among EU countries. The threat of future development is mainly fast aging of population, low natality and changes in the structure of the economy and employment (Urbaníková, M.; Štubňová, M. (2018)).

The Slovak Republic consists of 8 self-governing regions, whose administration is independent of the central state power, and 79 districts (Papcunová, V.; Urbaníková, M.; Korenková, M. (2016), Papcunova, V., Hudakova, J., Beresecká, J. (2018)). The largest regions in terms of population are the Košice and Prešov self-governing regions, the population density of the Bratislava self-governing region stands out (294 inhabitants per $\mathrm{km}^{2}$ ). The level of development of regions within the Slovak Republic, determined for example by the quality of road infrastructure (especially motorways and roads for motor vehicles), the inflow of foreign investment and the related level of wages and unemployment rate of the population, still varies considerably. In general, the regions in the west (Bratislava, Trnava self-governing region) are more developed than the central (Banská Bystrica selfgoverning region) or eastern (Prešov, Košice self-governing region) regions of Slovakia. The highest unemployment and the corresponding lowest wages are recorded in the Prešov and Banská Bystrica regions, in the Bratislava and Trnava self-governing regions the situation is exactly the opposite (Levický, M. et al. (2019); Maroš, M.; Rybanský, L'. (2016)). The government is trying to implement tools that would reduce existing regional disparities (Dušek, J. (2017)).

In connection with the more developed infrastructure and proximity of trans-European transport networks, several foreign investors in the Slovak Republic preferred the west of the country. In the Žilina, Trnava and Bratislava regions, automotive clusters around KIA (Žilina City), PSA Peugeot (Trnava City) and Volkswagen (Bratislava City) were naturally established, while in the Trnava City and Nitra City regions an electrical cluster was formed around Samsung (Galanta City, Voderady City), Foxconn (Nitra City), supplemented by AU Optronics (Trenčín City). Steel production has a tradition in the Košice self-governing region, where the company U.S. Steel Košice, chemical production in the Prešov region (Humenné City) and Trenčín region (Púchov City) self-governing regions, while the wood processing industry is concentrated mainly in the central part of the country (Banská Bystrica self-governing region). Despite the fact that the country has potential in the field of tourism development (Beresecká, J. (2013)), this sector is not sufficiently established. Tourism began to play an important role as a tool of development regarding cross-border cooperations after the change of the regime. A more efficient cooperation is needed to employ the potentials in tourism-related development of environmental endowments as well as the significant improvement in standards of other factors (Bujdosó, Z. et al. (2015)). There are several industries in Slovakia with a long tradition, such as engineering, chemical, electrical, woodworking and food industries. Industry is currently undergoing a phase of rapid growth, not least due to a significant inflow of foreign investors (Fabuš, M.; Csabay, M. (2018)). Slovakia is currently becoming one of the world leaders in the automotive industry. The established Volkswagen factory in Bratislava City was joined by car manufacturers PSA in Trnava City, KIA Motors in Žilina City and Jaguar / Land-Rover in Nitra City. In the future, however, Slovakia would like to focus more on supporting production and services with a higher rate of added value, which is also related to the issue of economic security (Kelisek, A.; Klucka, J.; Ondrusek, M.; Strelcova, S. (2011)). One of Slovakia's strategic steps in supporting foreign investment is also significant investment support and the presentation of the domestic Slovak research and development environment. Research and development are among the key features of developed countries, the growth of the country's economic level, sustainable development and the promotion of a knowledge-based society and an innovation-based economy. Modern technologies, support for innovation, innovative business, creativity, education, building research and development centers, laboratories and test rooms 


\section{ENTREPRENEURSHIP AND SUSTAINABILITY ISSUES}

ISSN 2345-0282 (online) http://jssidoi.org/jesi/ 2020 Volume 8 Number 1 (September) http://doi.org/10.9770/jesi.2020.8.1(32)

are currently the most important areas for the progress of the whole country (Klement, L. (2017); Fil'a, M.; Kučera, J. (2016)). Slovakia is a country with a competitive technical background and a long tradition of industrial research and development. Slovakia has active research and development staff participating in top domestic and international projects. Slovakia has an accessible engineering and scientific base, it has built a Research \& Development (R\&D) network consisting of industrial research and development organizations, scientific research institutes at technical and natural sciences, research institutes of the Slovak Academy of Sciences. This R\&D base is also well connected with other interested institutions such as industry associations, unions, clusters, research, development and innovation support agencies, business innovation centers and incubators, science and technology parks, but also software development companies. Several foreign companies have already been convinced of the skills of Slovak researchers, developers and engineers (Urbaníková, M. (2017)), which have set up their R\&D centers in Slovakia, such as: Johnson Controls, ON Semiconductor, Leoni, BSH, ThermoSolar, Sauer Danfoss, Krauss Maffei, Ness, Siemens, Alcatel-Lucent, Mühlbauer, Continental Automotive Systems, Elastogran and others.

\section{Methodology}

In the case study, we deal with the achieved successes of international cooperation between Austria and Slovakia and identify open issues in bilateral relations between Slovakia and Austria, as well as outline trends in the coming period. The ambition of the study is also to highlight areas that can be considered key for bilateral cooperation. International cooperation is a very broad issue for which general and specific scientific methods can be used. Given the type of study, we chose to use selected general scientific methods, which we adapted to the specifics of examining economic relations between countries. We subjected the realities of countries and selected economic and social indicators of countries to a comparative analysis, in which we examined the similarities and differences in selected indicators. We used causal analysis to identify the causal relationships of selected indicators. In several cases, we examined the composition of the selected system, which was represented by a specific economic indicator, through a structural analysis. The sources of secondary data that we used in the case study were mainly publicly available data databases. The databases are accessible on the websites of the institutions of both countries. In particular, we used data from the Statistical Office of the Slovak Republic and the Republic of Austria, the National Bank of Slovakia, the Austrian National Bank, the Ministry of Economy of the Slovak Republic, the Ministry of the Interior of the Republic of Austria, and finally the Eurostat database. Important information was obtained from internal materials of the Slovak Investment and Trade Development Agency.

\section{Economic relations between Slovakia and Austria}

\subsection{Development of foreign trade between Slovakia and Austria}

Based on data from the Ministry of Economy of the Slovak Republic, the Statistical Office of the Slovak Republic, the Embassy of the Slovak Republic in Austria, data from the Slovak Chamber of Commerce and Industry and the Austrian Embassy in Bratislava, it can be seen that Slovakia 's foreign trade has been developing positively since 1993 . With the exception of 2009, which was marked by the impact of the economic crisis, foreign trade was growing. Trade between countries is growing every year, and as a result, in 2019, Austria ranked fourth in the ranking of the largest Slovak trade suppliers. In terms of per capita, the Slovak Republic has the second highest trade turnover with Austria. On the part of Austria, the Slovak Republic is Austria's eleventh most important trading partner.

As part of the development of foreign trade, in addition to individual indicators, different data from Slovak and Austrian statistical sources will also be interesting. For completeness, we present the statistics of the Ministry of Economy of the Slovak Republic, as well as the Statistical Office of Austria (see table 1 and table 2). 
Table 1. Data on foreign trade of Slovakia

\begin{tabular}{|c|c|c|c|c|c|c|}
\hline Category & $\begin{array}{c}\text { unit of } \\
\text { measure }\end{array}$ & 2015 & 2016 & 2017 & 2018 & 2019 \\
\hline Imports of goods from Austria & mil. $€$ & 1620 & 1953 & 2041.5 & 2348.5 & 2533.6 \\
\hline Share in total imports of the SR & $\%$ & 2.5 & 2.9 & 2.8 & 3.04 & 3.2 \\
\hline Export of goods to Austria & mil. $€$ & 3863 & 4010 & 4478.8 & 4540.2 & 4496.7 \\
\hline Share in total exports of the SR & $\%$ & 5.7 & 5.7 & 6.0 & 5.69 & 5.6 \\
\hline Foreign trade balance & mil. $€$ & 2243 & 2057 & 2437.3 & 2191.7 & 1963.1 \\
\hline
\end{tabular}

Source: Ministry of Economy of the Slovak Republic

Table 2. Data on foreign trade of Austria

\begin{tabular}{|c|c|c|c|c|c|c|}
\hline Category & $\begin{array}{c}\text { unit of } \\
\text { measure }\end{array}$ & 2015 & 2016 & 2017 & 2018 & 2019 \\
\hline Imports of goods from Slovakia & mil. $€$ & 2964 & 2946 & 2940 & 3498 & 3282 \\
\hline Share in total imports of Austria & $\%$ & 2.2 & 2.2 & 2.1 & 2.24 & 2.08 \\
\hline Export of goods to Slovakia & mil. $€$ & 2715 & 2808 & 3010 & 3185 & 3191 \\
\hline Share in total exports of Austria & $\%$ & 2.1 & 2.1 & 2.0 & 2.12 & 2.08 \\
\hline Foreign trade balance & mil. $€$ & -249 & -138 & -70 & -313 & -91 \\
\hline
\end{tabular}

Source: Statistical Office of Austria

The largest increase in exports was recorded in the Slovak Republic in 2018 to China, at $52.8 \%$ compared to the previous period. However, there was also a significant increase towards the Austrian economy - at the level of $20.9 \%$, while imports from Austria increased by $4.4 \%$, which results in a growing positive balance of foreign trade of the Slovak Republic and Austria (table 3, figure 1 and figure 2).

Table 3. Overview of mutual trade between the Slovak Republic and Austria in mil. $€$

\begin{tabular}{|c|c|c|c|c|c|c|c|c|c|c|c|}
\hline Category & 2009 & 2010 & 2011 & 2012 & 2013 & 2014 & 2015 & 2016 & 2017 & 2018 & 2019 \\
\hline Export & 2350 & 3271 & 3956 & 4100 & 3977.2 & 3965 & 3863 & 4010 & 4478.8 & 4540.2 & 4496.7 \\
\hline Import & 1006 & 1193 & 1245 & 1363 & 1535.3 & 1530 & 1620 & 1953 & 2041.5 & 2348.5 & 2533.6 \\
\hline Turnover & 3356 & 4464 & 5201 & 5463 & 5512.4 & 5495 & 5483 & 5963 & 6520.3 & 6888.7 & 7030.3 \\
\hline Balance & 1344 & 2078 & 2711 & 2737 & 2441.9 & 2436 & 2243 & 2057 & 2437.3 & 2191.7 & 1963.1 \\
\hline
\end{tabular}

Source: Ministry of Economy of the Slovak Republic 


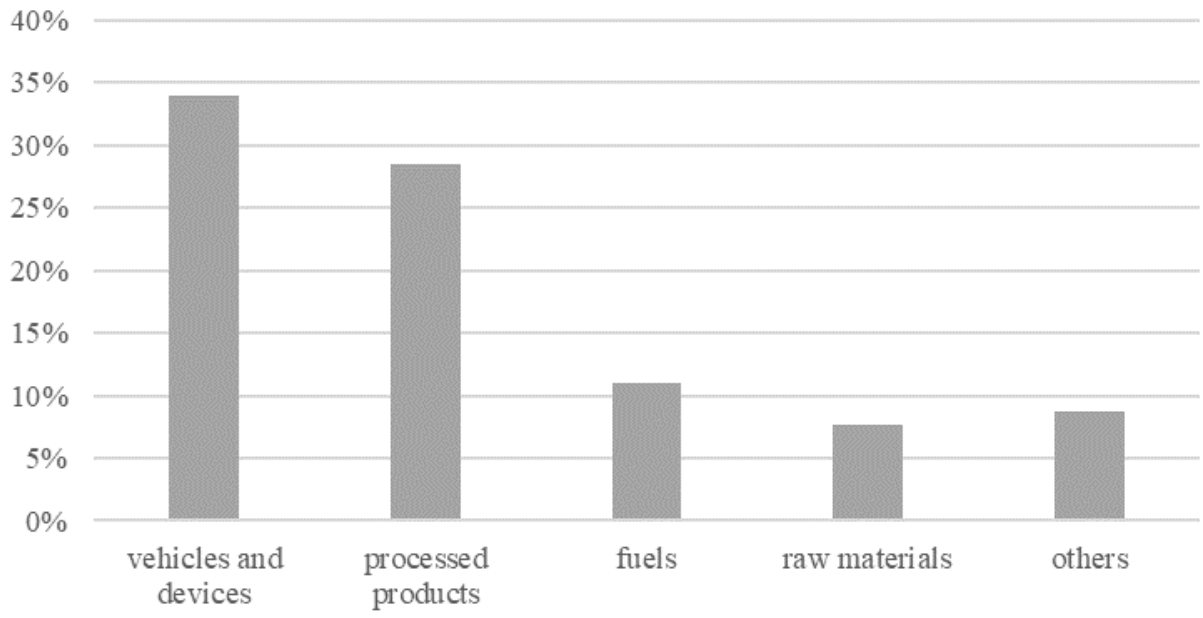

Figure 1. The most imported goods from Austria to Slovakia in 2019 (percentage share)

Source: Statistical Office of Austria

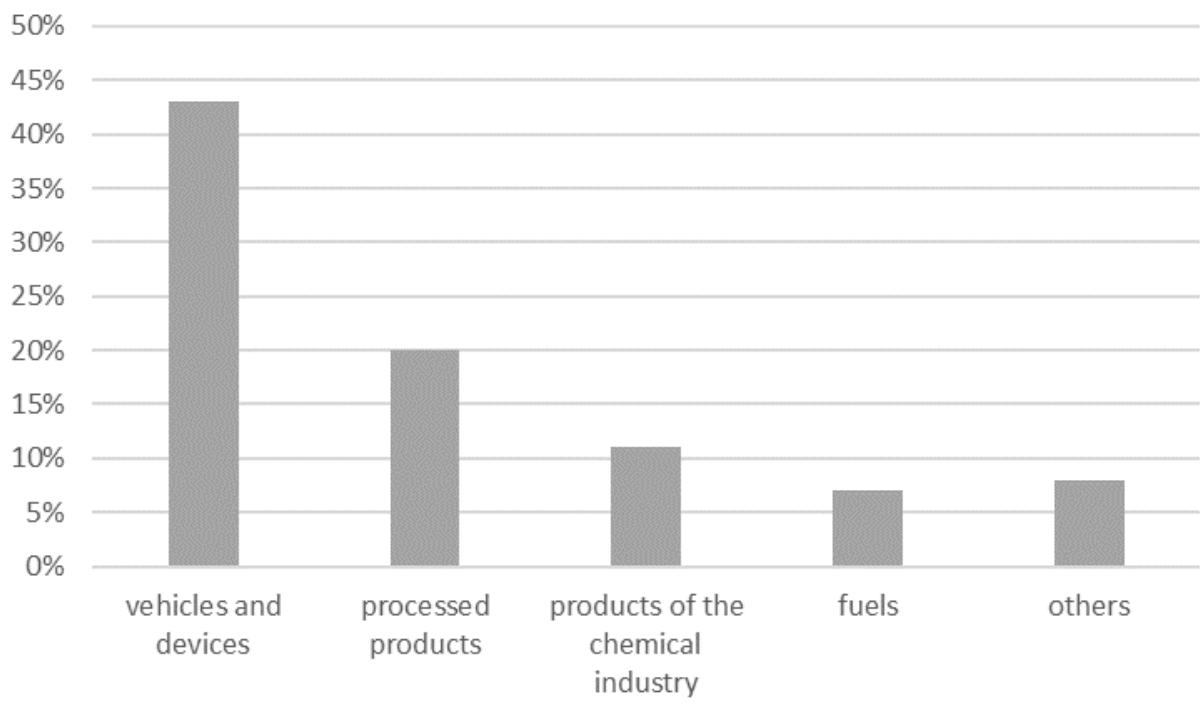

Figure 2. The most imported goods from Slovakia to Austria in 2019 (percentage share)

Source: Statistical Office of Austria

\subsection{Foreign direct investment between countries}

Austria is an important and large foreign investor, especially in Germany (24.8 billion $€$ ), the Netherlands (17.6 billion $€$ ) and the Czech Republic (10.6 billion $€$ ). It is one of the main investors in the countries of Central and Eastern Europe. Although these investments are undergoing changes as a result of political and economic developments (Ukrainian-Russian conflict, domestic political developments in Hungary, problems in the Western Balkans, etc.), Austria's position as a gateway to Central and Eastern Europe remains. A substantial part of Austrian foreign direct investment goes to financial and insurance services. In subsidiaries of Austrian companies 
abroad work 785 thousand employees. Austrian countries are among the most important employers in countries such as Romania, Slovenia, Croatia, Bosnia and Herzegovina and Serbia (table 3).

Table 3. Values of Austrian foreign direct investment

\begin{tabular}{|c|c|c|c|c|c|c|}
\hline Category & $\begin{array}{c}\text { unit of } \\
\text { measure }\end{array}$ & 2015 & 2016 & 2017 & 2018 & $2019^{*}$ \\
\hline $\begin{array}{c}\text { Value of Austria 's foreign } \\
\text { direct investment abroad }\end{array}$ & mil. $€$ & 188,509 & 186,891 & 194,031 & 202,973 & $\mathrm{n} / \mathrm{a}$ \\
\hline $\begin{array}{c}\text { Value of foreign direct } \\
\text { investment from abroad to } \\
\text { Austria }\end{array}$ & mil. $€$ & 146,706 & 142,920 & 163,536 & 176,333 & $\mathrm{n} / \mathrm{a}$ \\
\hline * data unavailable Source: Austrian National Bank
\end{tabular}

Austria is the second largest investor in the Slovak Republic (after the Netherlands), with a share of foreign direct investment in the Slovak Republic of $16 \%$. Austrian companies employ 44500 employees in their subsidiaries and branches in the Slovak Republic. According to the data of the Austrian National Bank, in 2016 the value of Austrian foreign direct investment in the Slovak Republic was 5856 billion $€$. The National Bank of Slovakia will register $€ 6.64$ billion in foreign direct investment from Austria by 2016. Austrian companies in Slovakia are not among the largest (except for banks, which are in the 1st and 3rd place), they are rather small and medium-sized companies, but there are more than 2000 in Slovakia and they use their lead in the field of know-how. The Slovak government is constantly implementing measures to improve the business environment. Also, conditions for business of a state have an influence on its attractiveness for potential foreign investments (Fabuš, M. (2017)).

Table 4. Values of Slovakian foreign direct investment

\begin{tabular}{|c|c|c|c|c|c|c|}
\hline Category & $\begin{array}{c}\text { unit of } \\
\text { measure }\end{array}$ & 2015 & 2016 & 2017 & 2018 & $2019^{*}$ \\
\hline $\begin{array}{c}\text { Value of Slovakia 's foreign } \\
\text { direct investment abroad }\end{array}$ & thousand $€$ & 2261572 & 2496000 & 43827038 & 4004940 & $\mathrm{n} / \mathrm{a}$ \\
\hline $\begin{array}{c}\text { Value of foreign direct } \\
\text { investment from abroad to } \\
\text { Slovakia }\end{array}$ & thousand $€$ & 42265453 & 45150265 & 49619706 & 51042587 & $\mathrm{n} / \mathrm{a}$ \\
\hline
\end{tabular}

Source: National Bank of Slovakia

In comparison, the Slovak foreign direct investment in Austria in the amount of 151 mil. $€$ much smaller (table 4). These are mainly small and medium-sized business, technological, construction, construction-supply, engineering and metalworking companies and companies in the field of IT, tourism and social services. The latest closed investment projects in 2018 show us how Austrian companies are establishing themselves in Slovakia (Table 5). 
ENTREPRENEURSHIP AND SUSTAINABILITY ISSUES

ISSN 2345-0282 (online) http://jssidoi.org/jesi/

2020 Volume 8 Number 1 (September)

http://doi.org/10.9770/jesi.2020.8.1(32)

Table 5. Overview of successfully completed investment projects of the SARIO agency in 2018

\begin{tabular}{|c|c|c|c|c|c|c|c|}
\hline Company name & $\begin{array}{c}\text { Investor's } \\
\text { home country }\end{array}$ & $\begin{array}{c}\text { New } \\
\text { investition/ } \\
\text { Expansion } \\
(\mathrm{N} / \mathrm{E})\end{array}$ & $\begin{array}{l}\text { Amount of } \\
\text { investment } \\
\text { in mil. } €\end{array}$ & $\begin{array}{l}\text { Number } \\
\text { of jobs } \\
\text { created }\end{array}$ & Sector & $\begin{array}{l}\text { Description of } \\
\text { activities }\end{array}$ & $\begin{array}{c}\text { Investment } \\
\text { location } \\
\text { (City of SR) }\end{array}$ \\
\hline J-Technics & Belgium & $\mathrm{N}$ & 1.00 & 10 & $\begin{array}{c}\text { Engineering } \\
\text { industry }\end{array}$ & $\begin{array}{c}\text { Production of gates } \\
\text { and fences }\end{array}$ & $\begin{array}{c}\text { Rimavská } \\
\text { Sobota }\end{array}$ \\
\hline $\begin{array}{c}\text { SPC } \\
\text { Technologies } \\
\text { AG }\end{array}$ & Switzerland & $\mathrm{N}$ & 1.50 & 40 & $\begin{array}{l}\text { Engineering } \\
\text { industry }\end{array}$ & $\begin{array}{l}\text { Production of carbon } \\
\text { fiber parts for bicycles }\end{array}$ & Vlkanová \\
\hline $\begin{array}{c}\text { Kamenárstvo } \\
\text { Ulický }\end{array}$ & Slovakia & $\mathrm{E}$ & 2.60 & 25 & $\begin{array}{c}\text { Stone } \\
\text { processing }\end{array}$ & $\begin{array}{c}\text { Production of stone } \\
\text { plate }\end{array}$ & $\begin{array}{l}\text { Rimavské } \\
\text { Zálužany }\end{array}$ \\
\hline ZF Slovakia & Germany & $\mathrm{N}$ & $\begin{array}{l}0 \text { (no new } \\
\text { machines) }\end{array}$ & 250 & $\begin{array}{l}\text { Automobile } \\
\text { industry }\end{array}$ & $\begin{array}{c}\text { Production of } \\
\text { stabilizers }\end{array}$ & Detva \\
\hline $\begin{array}{c}\text { SAM } \\
\text { Automotive }\end{array}$ & Germany & $\mathrm{N}$ & 50.00 & 800 & $\begin{array}{c}\text { Automobile } \\
\text { industry }\end{array}$ & $\begin{array}{c}\text { Production of } \\
\text { aluminum parts }\end{array}$ & Vel'ký Krtíš \\
\hline $\begin{array}{c}\text { Dongil Rubber } \\
\text { Belt }\end{array}$ & South Korea & $\mathrm{E}$ & 19.17 & 150 & $\begin{array}{c}\text { Automobile } \\
\text { industry }\end{array}$ & Production of seals & $\begin{array}{c}\text { Považská } \\
\text { Bystrica }\end{array}$ \\
\hline Intercable & Italy & $\mathrm{N}$ & 10.00 & 255 & $\begin{array}{c}\text { Automobile } \\
\text { industry }\end{array}$ & $\begin{array}{l}\text { Production of high- } \\
\text { voltage equipment }\end{array}$ & Kriváň \\
\hline Optotune & Switzerland & $\mathrm{N}$ & 0.52 & 150 & $\begin{array}{l}\text { Electro } \\
\text { technical } \\
\text { industry } \\
\end{array}$ & $\begin{array}{l}\text { Production of } \\
\text { optoelectronic } \\
\text { components }\end{array}$ & Trnava \\
\hline $\begin{array}{c}\text { Continental } \\
\text { Automotive } \\
\text { Systems }\end{array}$ & Germany & $\mathrm{E}$ & 47.50 & 150 & $\begin{array}{l}\text { Automobile } \\
\text { industry }\end{array}$ & $\begin{array}{l}\text { Production of brake } \\
\text { systems }\end{array}$ & Zvolen \\
\hline Mubea & Nemecko & $\mathrm{N}$ & 51.00 & 504 & $\begin{array}{c}\text { Automobile } \\
\text { industry }\end{array}$ & $\begin{array}{l}\text { Production of chassis } \\
\text { parts }\end{array}$ & Kežmarok \\
\hline $\begin{array}{c}\text { Oerlikon } \\
\text { Balzers }\end{array}$ & Liechtenstein & $\mathrm{E}$ & 10.00 & 100 & Metallurgy & $\begin{array}{l}\text { Surface treatment of } \\
\text { metals and plastics }\end{array}$ & Vel'ká Ida \\
\hline $\begin{array}{c}\text { Lander } \\
\text { Automotive }\end{array}$ & $\begin{array}{c}\text { United } \\
\text { Kingdom }\end{array}$ & $\mathrm{N}$ & 2.50 & 118 & $\begin{array}{c}\text { Automobile } \\
\text { industry }\end{array}$ & $\begin{array}{c}\text { Production of fuel } \\
\text { systems }\end{array}$ & Galanta \\
\hline Smartwood & $\begin{array}{c}\text { Czech } \\
\text { Republic }\end{array}$ & $\mathrm{N}$ & 5.00 & 50 & $\begin{array}{c}\text { Wood } \\
\text { processing }\end{array}$ & $\begin{array}{c}\text { Production of food } \\
\text { packaging }\end{array}$ & Strážske \\
\hline De Heus & Netherlands & $\mathrm{N}$ & 6.00 & 40 & $\begin{array}{l}\text { Manufacturing } \\
\text { industry }\end{array}$ & Feed production & $\begin{array}{c}\text { Kendice p. } \\
\text { Prešove }\end{array}$ \\
\hline Forlit & $\begin{array}{c}\text { Czech } \\
\text { Republic }\end{array}$ & $\mathrm{N}$ & 8.70 & 136 & paper industry & $\begin{array}{c}\text { Production of paper } \\
\text { panels }\end{array}$ & Fil'akovo \\
\hline Kistler & Switzerland & $E$ & 0.20 & 100 & informatics & Software development & Žilina \\
\hline Pulsar Expo & $\begin{array}{c}\text { Czech } \\
\text { Republic }\end{array}$ & $\mathrm{N}$ & 7.00 & 220 & $\begin{array}{c}\text { Automobile } \\
\text { industry }\end{array}$ & $\begin{array}{c}\text { Production of } \\
\text { transport parts }\end{array}$ & Horné Sŕnie \\
\hline Karloff & Slovakia & $\mathrm{E}$ & 2.10 & 25 & Food industry & $\begin{array}{c}\text { Production of } \\
\text { decorative bottles }\end{array}$ & Kežmarok \\
\hline $\begin{array}{l}\text { Diebold } \\
\text { Nixdorf }\end{array}$ & Germany & $\mathrm{E}$ & 5.00 & 80 & Informatics & IT infrastructure & Košice \\
\hline $\begin{array}{c}\text { Pankl } \\
\text { Automotive }\end{array}$ & Austria & $\mathrm{E}$ & 12.00 & 120 & $\begin{array}{c}\text { Automobile } \\
\text { industry }\end{array}$ & $\begin{array}{c}\text { Production of } \\
\text { propulsion systems }\end{array}$ & Topol'čany \\
\hline Adient & USA & $\mathrm{E}$ & 3.50 & 105 & $\begin{array}{c}\text { Automobile } \\
\text { industry }\end{array}$ & $\begin{array}{c}\text { Production of parts of } \\
\text { seats }\end{array}$ & Lučenec \\
\hline EMI-Sabinov & Slovakia & $\mathrm{N}$ & 0.70 & 13 & Textile industry & $\begin{array}{l}\text { Production of bed } \\
\text { linen }\end{array}$ & Sabinov \\
\hline MEMOLAK & Slovakia & $\mathrm{N}$ & 0.60 & 10 & Metallurgy & $\begin{array}{c}\text { Surface treatment of } \\
\text { metals }\end{array}$ & Lučenec \\
\hline Brose Prievidza & Germany & $\mathrm{E}$ & 57.40 & 350 & $\begin{array}{l}\text { Automobile } \\
\text { industry }\end{array}$ & $\begin{array}{l}\text { Production of } \\
\text { mechatronic } \\
\text { components }\end{array}$ & Prievidza \\
\hline $\begin{array}{c}\text { Neuman } \\
\text { Aluminium }\end{array}$ & Austria & $\mathrm{E}$ & 11.50 & 215 & Metallurgy & $\begin{array}{l}\text { Metal processing for } \\
\text { motor vehicles }\end{array}$ & Žarnovica \\
\hline Klauke & Germany & $\mathrm{E}$ & 2.00 & 150 & Electro industry & $\begin{array}{c}\text { Production of } \\
\text { connectors }\end{array}$ & Gelnica \\
\hline
\end{tabular}

Source: Slovak Investment and Trade Development Agency, Annual Report 2018 


\section{ENTREPRENEURSHIP AND SUSTAINABILITY ISSUES}

ISSN 2345-0282 (online) http://jssidoi.org/jesi/

2020 Volume 8 Number 1 (September)

http://doi.org/10.9770/jesi.2020.8.1(32)

\subsection{Field of research and development}

Innovative activities in support of the business environment, not only in technology, research and development, are generally the driving force behind economic development. The scientific and technical environment is made up of for-profit and non-profit institutions that deal with scientific research, development of new materials, methods and products.

Developments in Austria over the last 10 years have been characterized by stagnation to a slight decrease in energy consumption, a structural shift away from petroleum and coal, and an increase in the share of renewable energy sources. In 2017, up to $72 \%$ of total electricity consumption in Austria was produced from renewable energy sources. The production of district heating from renewable energy sources increased by about $3 \%$, with about $48 \%$ of the district heating used being produced from renewable energy sources. Austria's foreign dependence increased by 2 percentage points to $64 \%$ compared to the previous year. This increase is mainly due to the foreign trade flow of natural gas. Austria has only low reserves of fossil fuels, which in turn offsets the high level of use of renewable energy sources. In terms of final consumption, transport, industrial production and energy consume the most energy from domestic and imported petroleum, gas and coal. Hydro and wind power plants produce electricity for the economy and households, biomass and solar energy, together with natural gas, oil and coal, are used to produce heat. It is assumed a high potential for renewable electricity expansion in combination with low financial prosperity is most likely to lead to a successful expansion of renewable electricity production from wind and photovoltaics (Wurster, S.; \& Hagemann, C. (2019)). Austria is committed to meeting international climate and energy goals. The main goal of the Federal Government's climate and energy policy (Mission 2030), approved in May 2018, is to reduce greenhouse gas emissions by $36 \%$ by 2030 compared to 2005. For this reason, the federal government has taken an important decision to develop an integrated climate strategy and energy to adopt a consistent path of decarbonisation by 2050. Maintaining a high level of energy security and becoming less dependent on energy imports is a top priority in the transformation of the energy system. The share of renewable energies in Austria is currently around 33.5\%. The share of electricity production from renewable energy sources reached $72 \%$ (in the EU on average $28 \%$ ). The Austrian government has set a target to cover $100 \%$ of electricity consumption from renewable energy sources by 2030 . The government puts more emphasis on transport in the Strategy. In freight transport, it will be a transfer to the railways; in road transport, it will promote low and zero emission vehicles. Alternative propulsion systems and fuels based on renewable energy sources will benefit. However, significant changes in the structure of buildings and in means of transportation are necessary, as well as the implementation of the Smart cities concept (Hummel, M.; Windsperger, A. (2009), Strielkowski, W. et al. (2020), Tvaronavičiené, M. (2018)).

Austrian expenditure on science, research and innovation in 2017 represented $3.16 \%$ of GDP. According to the European Commission, the country is in second place in terms of research intensity. The competence of supporting science, research and innovation in Austria is shared by the Federal Ministry of Transport, Innovation and Technology and the Federal Ministry of Education, Science and Research. The advisory institutions are the Research and Technological Development Council and the Austrian Scientific Council.Publicly subsidized, autonomous funds have been set up to support research and technology. The central institution supporting technology research and innovation in the field of applied research is the Austrian company to support 100\% state-owned research. The Fund for the Support of Scientific Research is an independent central institution for the support of basic research in Austria. Private funding is provided through Grunderfond and Business Angels, as well as through individual initiatives. The platform www.forschungsatlas.at provides an overview of specific scientific research institutions and projects. According to the Austrian Statistical Office, R\&D intensity increased to $3.19 \%$ ( 12.3 billion $€$ ) in 2018. In 2018, the government sector financed research and development in the amount of 4.2 billion $€$, which is $4.3 \%$ more than in 2017. Almost 3.56 billion $€$ was spent from the federal 
government. Approximately 526 mil. $€$ comes from regional governments. Other public institutions contributed approx. 117 mil. $€$. Funding from the private non-profit sector is at the level of 71 mil. $€$.

The share of gross expenditure on research and development in GDP in Slovakia is very low compared to the EU. Compared to other EU countries, Slovakia is one of the worst ranked countries. In 2015, there was an increase in expenditure on research and science, due to the exhaustion of structural funds. Subsequently, it also had an impact on the increase in the number of persons employed in 2016. Since 2015, the share of expenditures has decreased, but even so, the number of science and research employees has been growing. In 2018, the largest number of employees in the research and development sector is recorded so far (Stachová, K. et al. (2018)). Most employees in research and development in Slovakia worked in the university sector $(47.6 \%)$, followed by the business sector $(29.7 \%)$ and the government sector $(22.2 \%)$. In the field of sciences, most employees work in technical sciences (43.9\%), natural sciences $(17.1 \%)$ and social sciences $(14.9 \%)$. In the last 4 years, there has also been a large increase in the number of employees in the business sector (Statistical Office of Slovak Republic). Figure 3 shows the evolution of the structure of R\&D expenditure. In 2017, the share of business resources represented $49 \%$ of the total expenditure structure (figure 3).

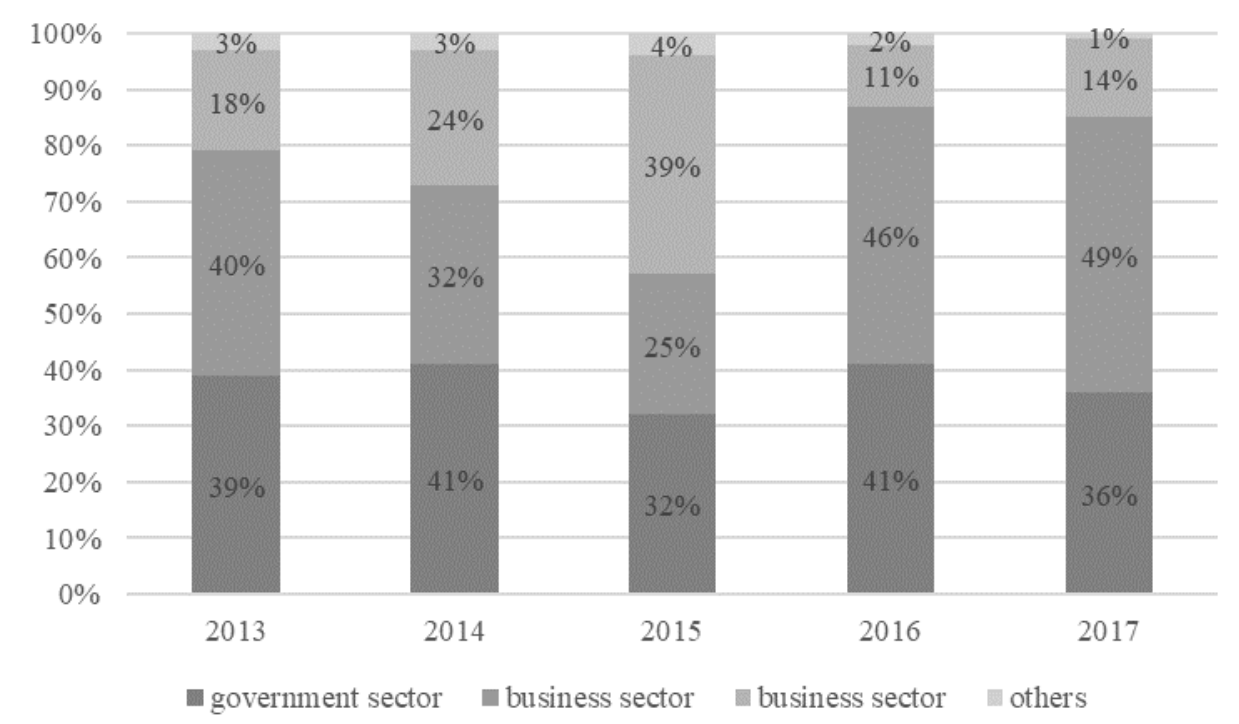

Figure 3. Development of the structure of expenditure on research and development by source of funding

Source: Statistical Office of the Slovak Republic

The Ministry of Economy of the Slovak Republic acts as a guarantor and coordinator of many activities (Sidak, M. et al. (2020)). Within the Ministry of Economy of the Slovak Republic, important programs to support enterprises include the Operational Program Research and Innovation and the Agency for Support of Research and Development. The business sector has long the largest share in research and development expenditures. In the field of scientific disciplines, the government sector mostly supports technical sciences $(58.77 \%)$, which also have the most employed researchers. This is followed by natural sciences with a share of $19.86 \%$, followed by social sciences, humanities, medicine and pharmaceutical sciences. Agricultural sciences receive the least support funds (Report on provided state aid in the Slovak Republic for 2018). The most serious problem in Slovakia in the field of technology and innovation is the low level of investment in science, research and innovation. Compared to the EU average, Slovakia is one of the lowest countries in the EU. The share of R\&D expenditure in 2018 was $0.88 \%$ of GDP, while the EU average was $2.12 \%$. Slovakia has implemented the largest share in the field of research and development in the business sector. The business sector accounted for almost 50.4\%, but is still below the EU 


\section{ENTREPRENEURSHIP AND SUSTAINABILITY ISSUES}

ISSN 2345-0282 (online) http://jssidoi.org/jesi/ 2020 Volume 8 Number 1 (September) http://doi.org/10.9770/jesi.2020.8.1(32)

average (60\%). Support should be increased in the private sector, with an emphasis on micro-enterprises, which need the most support. Financial support for research and development from the EU structural and investment funds represents a great opportunity for Slovakia.

\section{Conclusion}

The economic policies of many countries, including Slovakia, favor active investor support through investment incentives. Although international agreements do not, in principle, allow discrimination against foreign or domestic investors, differences in treatment often result from set criteria that an investor must meet in order to obtain these incentives. In the Slovak Republic, small and medium-sized enterprises predominate, and they often cannot meet the criterion of a minimum volume of investment, so it is most often foreign investors who benefit from investment incentives. Based on the results, we can say that the possibilities of economic cooperation between Austria and Slovakia are far from exhausted. Joint projects in the field of transport and energy infrastructure, energy security and diversification of energy sources are several examples where cooperation lasts for several years and has a perspective for the future. The increase in cooperation is in the field of foreign trade, in the field of foreign investment, but also in the growing level of services, including the increase in cooperation in the field of tourism. Since its inception, Slovakia has become an important trading partner of Austria, with trade with Austria catching up with trade. Slovakia with traditional partners - with neighbors (Poland, Hungary). Strategic interconnection at the core of the euro area together with a peripheral geographical position Austria and Slovakia in the east of the EU create preconditions for a new intensity of bilateral dialogue between the two countries on key issues of European integration. In the context of resolving the debt crisis, both countries were included among the so-called countries of the north, which in the first years of debt crisis, an emphasis on accountability and fiscal stability. Unlike Austria and Slovakia the surrounding lands experienced significant fluctuations in national currencies during this period. At the same time, both countries are in the position of countries that have the potential to build bridges of cooperation and dialogue with countries seeking membership of the euro area, with a special interest in Slovakia is to maintain the highest possible degree of political and economic cohesion between members of the euro area and other EU countries, in particular neighboring Visegrad countries. There is real potential for strategic dialogue and a closer partnership between Austria and Slovakia, in particular as regards the functioning of the euro area, EU enlargement in the Western Balkans and deepening relations with its eastern neighbors EU (Benč, V. et al. (2013); Slovak Investment and Trade Developmen (2018)).

\section{References}

Antimonopoly Office of the Slovak Republic. (2019). Report on provided state aid in the Slovak Republic in 2018. Retrieved January 20, 2020 from URL http://www.statnapomoc.sk/wp-content/uploads/2018/06/Obal.pdf

Austrian National Bank. Open databases. Retrieved January 16, 2020 from URL https://www.oenb.at/en/Statistics.html

Austrian Interior Ministry. (2019) The results of the elections in Austria in 2019. Retrieved January 20, 2020 from URL https://wahl19.bmi.gv.at/

Benč, V., et al. (2013). Two decades of Slovak-Austrian relations. Retrieved January 18, 2020 from URL http://www.sfpa.sk/wpcontent/uploads/2015/12/kniha sk web.pdf

Beresecká, J. (2013). Natural and Cultural-historical potential - a catalyst for tourism development. In Klímová, V., Žítek, V. (eds.) 16nd International Colloquium on Regional Sciences. Conference Proceedings. Brno: Masaryk University Press, 2013. pp.603-609. https://doi.org/10.5817/CZ.MUNI.P210-6257-2013-76 


\section{ENTREPRENEURSHIP AND SUSTAINABILITY ISSUES}

ISSN 2345-0282 (online) http://jssidoi.org/jesi/ 2020 Volume 8 Number 1 (September) http://doi.org/10.9770/jesi.2020.8.1(32)

Bujdosó, Z., et al. (2015). Tourism development and cross-border cooperation in the Hungarian-Romanian border region. GeoJournal of Tourism and Geosites, 2015, 16.2: 153-163.

Christl, M., Köppl-Turyna, M., \& Kucsera, D. (2016). Structural unemployment after the crisis in Austria. IZA Journal of European Labor Studies, 5(1), 12. https://doi.org/10.1186/s40174-016-0062-5

Dušek, J. (2017). Evaluation of development of cooperation in South Bohemian municipalities in the years 2007-2014. European Countryside, 9(2), 342-358. http://dx.doi.org/10.1515/euco-2017-0021

Economist Intelligence Unit. (2019). Democracy Index 2019. Economist Intelligence Unit. Retrieved January 6, 2020 from URL https://www.eiu.com/topic/democracy-index

Eurostat. Open databases. Retrieved February 20, 2020 from URL https://ec.europa.eu/eurostat/data/database

Fabuš, M. (2017). Current development of business environment in Slovakia and Czech Republic. Entrepreneurship and Sustainability Issues, 5(1), 127-137. https://doi.org/10.9770/jesi.2017.5.1(10)

Fabuš, M., Csabay, M. (2018). State aid and investment: case of Slovakia. Entrepreneurship and Sustainability Issues, 6(2), 480-488. http://dx.doi.org/10.9770/jesi.2018.6.2(1)

Federal Ministry of Education, Science and Research of Austria. Overview of scientific research institutions and projects. Retrieved February 1, 2020 from URL $\underline{\text { www.forschungsatlas.at }}$

Fil'a, M., Kučera, J. (2016). Innovation performace of the Slovak Republic. Geografické informácie, 70. http://dx.doi.org/10.17846/GI.2016.20.2.70-81

Graf, L. (2016). The rise of work-based academic education in Austria, Germany and Switzerland. Journal of Vocational Education \& Training, 68(1), 1-16. https://doi.org/10.1080/13636820.2015.1107749

Horvath, P. (2017). Dualism of executine power in the Slovak Republic. Politické vedy, 20(1), 47-63.

Hummel, M., \& Windsperger, A. (2009). Sustainable energy future for Austria. WIT Transactions on Ecology and the Environment, 127, 303-311. http://dx.doi.org/10.2495/RAV090271

Jeníček, V. (2002). Globalization of the world economy. 1nd ed. Praha: C. H. Beck, 152 p., ISBN 80-7179-787-1.

Kelisek, A., Klucka, J., Ondrusek, M., \& Strelcova, S. (2011). Economic security-A principal component of multilevel security concept in global economy. Communications-Scientific letters of the University of Zilina, 13(2), 44-48.

Kincl, M. (2003). Investment incentives as a form of public support. Praha: Linde nakladatelství, 79 p., ISBN 80-86131-48-3.

Klement, L. (2017). State support system of innovations in Slovakia. Innovation Management, Entrepreneurship and Sustainability, pp. 404-415.

Lasinger, D., Halusa, G., Docekal, J. (2011). Survey of the Austrian Economy. 1nd ed. Wien: Wirtschaftsstudio des Österreichischen Wirtschafts- und Gesellschaftsmuseum, 95 p., ISBN 978-3-7007-4741-3.

Levický, M. et.al. 2019. Convergence tendencies in the conditions of regions of the Slovak Republic. In Klímová, V., Žítek, V. (eds.) 22nd International Colloquium on Regional Sciences. Conference Proceedings. Brno: Masaryk University Press, 2019. pp. 1-5. ISBN 978-80210-9268-6. http://dx.doi.org/10.5817/CZ.MUNI.P210-9268-2019-2

Lomachynska, I., Yakubovskiy, S., \& Plets, I. (2019). Dynamics of Austrian foreign direct investment and their influence on the national economy. Baltic Journal of Economic Studies, 4(5), 167-174. https://doi.org/10.30525/2256-0742/2018-4-5-167-174

Luif, P. (2016) Austria and the European Union. Oxford Research Encyclopedia of Politics.

https://dx.doi.org/10.1093/acrefore/9780190228637.013.185

Maroš, M., Rybanský, L. (2016). Development of Wage Disparities in Slovakia and the Use of Quantitative Methods for their Analysis. In Klímová, V., Žítek, V. (eds.) 19nd International Colloquium on Regional Sciences. Conference Proceedings. Brno: Masaryk University Press, 2017, 387-391. http://dx.doi.org/10.5817/CZ.MUNI.P210-8273-2016-49 


\section{ENTREPRENEURSHIP AND SUSTAINABILITY ISSUES}

ISSN 2345-0282 (online) http://jssidoi.org/jesi/ 2020 Volume 8 Number 1 (September)

http://doi.org/10.9770/jesi.2020.8.1(32)

Meier, M. (2011). Der Holdingstandort Österreich. Ost-West Contact, 57(11), ISSN 0948 - 1680.

Ministry of Foreign Affairs and European Affairs of the Slovak Republic. (2019). Economic information on the territory: Republic of Austria. Retrieved February 4, 2020 from URL https://www.mzv.sk/documents/10182/620840/Rak\%C3\%BAsko++ekonomick\%C3\%A9+inform\%C3\%A1cie+o+terit\%C3\%B3riu+2019

National Bank of Slovakia. Open databases. Retrieved February 10, 2020 from URL https://www.nbs.sk/en/statistics

Papcunová, V., Hudaková, J., Beresecká, J. (2018). Changes in the local self-government in the conditions of Slovak Republic per 25 years. Geographical information, 22, 223-231. http://dx.doi.org/10.17846/GI.2018.22.2.223-231

Papcunová, V., Urbaníková, M., Korenková, M. (2016). Financing of transferred execution of the state administration in the field of registry offices on the local self-government in the Slovak Republic. In Klímová, V., Žitek, V. (eds.) 19nd International Colloquium on Regional Sciences. Conference Proceedings. Brno: Masaryk University Press, 2016. pp. 788-795. https://doi.org/10.5817/CZ.MUNI.P210$\underline{8273-2016-101}$

Popescu, A. (2017). Trends in tourism demand in the top visited European Countries. Scientific Papers-Series Management Economic Engineering in Agriculture and Rural Development, 17(4), 243-254.

Prno, I. (2010). Clusters - new tools of economic development. Retrieved February 20, 2020 from URL http://www.milan.laurencik.sk/wpcontent/uploads/2010/04/klaster.pdf

Rengs, B., et al. (2017). Labour market profile, previous employment and economic integration of refugees: An Austrian case study. Vienna Institute of Demography Working Papers, 2017. https://doi.org/10.13140/RG.2.2.35356.39048

Republik Österreich - Parlament. (2008). Austrian Parliament. Retrieved January 20, 2020 from URL http://www.parlament.gv.at/LANG/ZUSD/PDF/SK.pdf

Rostetska, S., \& Naumkina, S. (2019). Paradigms of european integration processes in the EU, visegrad group, and Ukraine. Baltic Journal of Economic Studies, 5(3), 184-192. https://doi.org/10.30525/2256-0742/2019-5-3-184-192

Schulze, M. S., \& Wolf, N. (2012). Economic nationalism and economic integration: the Austro-Hungarian Empire in the late nineteenth century 1. The economic history review, 65(2), 652-673.

Sidak, M., Cibák, L., Hajnišová, E. (2020). Investment protection: determination of legal aspects with reflecting to the innovations to ensure sustainable growth of the Slovak Republic, Entrepreneurship and Sustainability Issues 7(3): $2350-2362$. https://doi.org/10.9770/jesi.2020.7.3(59)

Slovak Investment and Trade Development Agency. (2011). Warum Slowakei?

Slovak Investment and Trade Development Agency. (2013). Invesment to $R \& D$.

Slovak Investment and Trade Development Agency. (2013). Why invest in Slovakia?

Slovak Investment and Trade Development Agency. Annual Report 2018. Retrieved February 9, 2020 from URL https://www.sario.sk/sites/default/files/data/sario-vyrocna-sprava-2018.pdf

Slovakia: Basic characteristics of the territory, economic overview. Retrieved February 9, 2020 from URL https://www.businessinfo.cz/navody/slovensko-zakladni-charakteristika-teritoria-ekonomicky-prehled/

Stachová, K. et al. (2018). Motivation of employees for creativity as a form of support to manage innovation processes in transportationlogistics companies. NA ̌́E MORE: znanstveno-stručni časopis za more i pomorstvo, 2018, 65.4 Special issue: $180-186$. https://doi.org/10.17818/NM/2018/4SI.3

Statistical Office of Slovak Republic. Open databases. Retrieved February 15, 2020 from URL https://slovak.statistics.sk Statistics Austria. Open databases. Retrieved February 22, 2020 from URL https://www.statistik.at/web_en/statistics/index.html

Strielkowski, W. et al. (2020). Economic efficiency and energy security of smart cities. Economic Research-Ekonomska Istraživanja, 33.1 (2020): 788-803. https://doi.org/10.1080/1331677X.2020.1734854 


\section{ENTREPRENEURSHIP AND SUSTAINABILITY ISSUES}

ISSN 2345-0282 (online) http://jssidoi.org/jesi/ 2020 Volume 8 Number 1 (September) http://doi.org/10.9770/jesi.2020.8.1(32)

Tóth, B. (2019). The V4 railway cooperation - Is there a homogeneous Visegrad Railway Area? Review of Economic Theory and Policy, 13(3), 158-177.

Tvaronavičienè, M. (2018). Towards sustainable and secure development: energy efficiency peculiarities in transport sector, Journal of Security and Sustainability Issues 7(4): 719-725. https://doi.org/10.9770/jssi.2018.7.4(9)

University of Alexander Dubček in Trenčín (SR). (2015). Partial outputs of the project of the 6th EU Framework Program "Development and implementation of a regional innovation strategy in the Trenčín region". Retrieved February 20, 2020 form URL http://ris.instit.sk

Urbaníková, M. (2017). Centers of Shared Services and their Impact on the Regions. In Klímová, V., Žítek, V. (eds.) 20nd International Colloquium on Regional Sciences. Conference Proceedings. Brno: Masaryk University Press, $2017 . \quad$ pp. $133-138$. http://dx.doi.org/10.5817/CZ.MUNI.P210-8587-2017-16

Urbaníková, M., Štubňová, M. (2018). The Quantitative Indicators Analysis of the Second Pillar of Pension System in V4 Countries. Geographical information, 22, 327-337. http://dx.doi.org/10.17846/GI.2018.22.2.327-337

Wurster, S., \& Hagemann, C. (2019). Expansion of Renewable Energy in Federal Settings: Austria, Belgium, and Germany in Comparison. SAGE Journals. https://doi.org/10.25384/SAGE.C.4763072

\section{Acknowledgements}

This paper was supported by the project, which has received funding from the Grant Research Agency of the School of Economics and Management in Public Administration in Bratislava, of the Slovak Republic. 


\section{ENTREPRENEURSHIP AND SUSTAINABILITY ISSUES}

ISSN 2345-0282 (online) http://jssidoi.org/jesi/ 2020 Volume 8 Number 1 (September) http://doi.org/10.9770/jesi.2020.8.1(32)

René PAWERA is the head of the Department of International Management at the Faculty of Management of Comenius University as a professor. He worked in several scientific-research, pedagogical and management workplaces of the army and the Ministry of the Interior and the university. He deals with issues of European security and regional economic policy. He is the author of dozens of foreign and domestic scientific articles, research reports, articles and several scientific monographs on security issues in the Slovak Republic and Europe, regional policy and equal opportunities in the labor market. He is also a author of a university textbook on security science and the leader of the author team of a textbook on regional economic policy in the European Union. As a lead researcher and co-researcher, he participated in several projects supported under the KEGA, VEGA and EQUAL schemes.

ORCID ID: https://orcid.org/0000-0003-0700-8243

František VOJTECH is an associate professor at the School of Economics and Management in Public Administration in Bratislava. He graduated from the Military High School in Management (1978). In 2004 he received a PhD degree at the Faculty of Management at Comenius University in Bratislava. In 2018 he was awarded the title of Associate Professor at the same school. For more than 30 years he has been involved in various management and control functions in the state administration, and he is also teaching the Regional Policy of the European Union, the Strategy of Socio-Economic Development

ORCID ID: https://orcid.org/0000-0003-3099-0108

Michal LEVICKÝ is a university lecturer and researcher at the University of Constantine the Philosopher in Nitra. He graduated from the Faculty of Economics and Management of the Slovak Agricultural University in Nitra (2010). In 2013 he received a PhD degree at the same school in the field of cross-cutting and sectoral economics. Currently he teaches disciplines Financial Analysis of Business, Business Economics, Finance and Banking, and National Economy Policy.

Researcher ID: E-9880-2019

ORCID ID: https://orcid.org/0000-0002-5297-1664

Stanislav FILIP is the Vice-Rector for academic project management of the School of Economics and management in Public Administration in Bratislava. His text books, monographs and scientific papers deal with the Risk and crisis managemtn in public sector, international crisis management and public administration at the national and EU level. He is succesfull leader and manager of the several scientific projects with support from the EU structural funds. He also organise and control international colaboration and Erasmus plus program with the high educational and research institutions in abroad.

Researcher ID: F-7984-2017

ORCID ID: https://orcid.org/0000-0003-3000-9383

Make your research more visible, join the Twitter account of ENTREPRENEURSHIP AND SUSTAINABILITY ISSUES: @Entrepr69728810

Copyright (C) 2020 by author(s) and VsI Entrepreneurship and Sustainability Center

This work is licensed under the Creative Commons Attribution International License (CC BY).

http://creativecommons.org/licenses/by/4.0/ 